\title{
Inkluzivní vzdělávání - obtížné zvládání „rozmanitosti“ v praxi
}

\section{Stanislav Štech}

Univerzita Karlova v Praze, Pedagogická fakulta, Katedra psychologie

Školní socializace stále rozmanitější žákovské populace po stále delší dobu je nesporně trendem, který vzdělávání v posledních více než sto letech charakterizuje snad nejvíce. Dvacáté století je sice podle díla Ellen Keyové nazývané stoletím dítěte, ale zrovna tak by mohlo být nazváno stoletím postupně rozšiřované scholarizace dětí ze všech sociálních vrstev, materiálně nebo kulturně bohatších stejně jako v tomto ohledu ochuzených, dívek stejně jako chlapců, zdravých i zdravotně postižených. Školní docházka se postupně prodlužuje a má stále více podobu společného vzdělávání všech zmíněných skupin. Výjimku tvoří případy návratu k rané selekci těch „nadanějších“, jako je tomu v případě víceletých gymnázií například v ČR. Z hlediska historické, tzv. dlouhé vlny se však ze školy, která byla na začátku 20. století „komplementem“ kulturní výchovy dětí střední třídy (srov. Tonucci, 1992), stala instituce poskytující základní předpoklady pro začlenění do společnosti všem dětem.

Zvládání této rozmanitosti ovšem přináší problémy pedagogické, zejména didaktické, i postojové. Od přelomu 80. a 90. let minulého století na ně upozorňují pedagogové a sociologové (např. Demailly, 1987). Konstatují, že učitelé se musejí vyrovnávat s novými požadavky na vzdělávání dětí ve škole. Jsou vyvolány především výše zmíněnou demokratizací vzdělávání vedoucí k masovému přístupu dětí ze všech sociálních vrstev a dětí s řadou znevýhodnění na stále vyšší stupně škol. To staví učitele před velice diverzifikovaný soubor žáků, což mu téměř znemožňuje bezproblémově aplikovat uniformní vyučovací postupy. A za druhé, žáci a jejich rodiny spatřují ve škole jednu z hlavních nadějí a možností, jak vůbec úspěšně vstoupit do života, mimo školu je taková cesta málo pravděpodobná. Vzniká tak souběh tlaků, který představuje nepř́ijemné břemeno pro učitelovo profesní sebepojetí. Na jedné straně si situace vynucuje didaktickou tvořivost, hledání způsobů, jak učivo přibližit velmi různě připraveným žákům, experimentovat s projektovými metodami na mezipředmětovém principu při zachování epistemologické čistoty jednotlivých předmětů ( $\mathrm{tj}$. naučit např. korektně matematicky myslet, obecně „remain true to the discipline“, viz Schleicher, 2018). Na druhé 
straně se nejen vědně-oborové poznatky promítnuté do učiva, ale i didaktické postupy stávají pro úspěšné vzdělávání pouhou podmínkou nutnou, nikoli však postačující, a změněná populace žákủ vyžaduje změnu pedagogických přesvědčení a postojů, včetně osvojení nových psychologických a sociologických poznatků. To jsme v podmínkách ČR zažili např́íklad v př́ípadě kurikulární reformy, jejíž ne zcela zdařilé provedení vyvolalo odlišné interpretace (Janík, 2013; Straková, 2013; Štech, 2013). Jádro těchto interpretací se však točí kolem dvou zmíněných tlaků na změnu. Aktuálním příkladem stejných tlaků je implementace další fáze začleňování žáků se speciálními vzdělávacími potřebami do běžných škol, označovaná jako společné vzdělávání. To se stalo frekventovaným tématem veřejných debat o vzdělávání. Postupně zesílily kritické hlasy a odmítavý postoj části pedagogické i laické veřejnosti $\mathrm{k}$ takzvané inkluzi.

Jak by tedy asi mohla znít jakási dlouhá věta inspirovaná slovem „inkluze“ a syntetizující názory na tento jev převažující ve veřejném prostoru? Pokusím se ji formulovat: jde o ideologický výmysl na pokyn Bruselu povinně nahánějící všechny děti s nějakým postižením do běžných škol; tento nápad nerozumí naší staré dobré tradici kvalitních speciálních škol, které zlikviduje, uškodí nejen žákům se speciálními vzdělávacími potřebami, ale i všem ostatním, zejména nadaným, které zpomalí v jejich vývoji; a ke všemu je to příliš drahé a nejsou na to peníze, které budou chybět na platech učitelů a dalších výdajích na školství. ${ }^{1}$

Taková obvinění si žádají argumentované zdůvodnění, proč k rozšíření a facilitaci společného vzdělávání v našich školách došlo. V tomto textu se budu věnovat nejprve pojmovému zmatku, který nastal $v$ souvislosti $\mathrm{s}$ inkluzivním vzděláváním a který je zdrojem řady nedorozumění. Dále upozorním na pedagogická a psychologická východiska společného vzdělávání a problémy, které vyvolává. A také považuji za potřebné na datech z prvního roku implementace kriticky ukázat rozdíl mezi „pohledem na distanc“ (celkové

\footnotetext{
Vzhledem k odbornému žánru textu se nebudu podrobněji vyjadřovat k politickému kontextu implementace další fáze inkluzivního vzdělávání u nás. Polemickou stat’ může čtenář nalézt zde: http://denikreferendum.cz/clanek/26672-bludy-kolem-takzvane-inkluze. Velmi podrobně jsem „český případ“ obecného trendu posilování inkluzivního vzdělávání v Evropě prezentoval na mezinárodní konferenci ECNAIS (European Council of National Associations of Independent Schools) Inclusion in Education, která se konala v Praze ve dnech 23. až 25. listopadu 2017 a organizovalo ji Sdružení soukromých škol Čech, Moravy a Slezska (základní informace a prezentace mého vystoupení zde: http://www.msmt.cz/ministerstvo/novinar/ministr-stech-na-seminari-inkluze-ve-vzdelavani).
} 
statistiky) a pohledem „zevnitř“, tj. mezi etic a emic přístupem. Tento rozdílný pohled je podle mě základem neporozumění ve sporech o takzvanou inkluzi.

\section{Zmatení pojmů aneb o čem vlastně mluvíme?}

Proč hovořit o „takzvané“ inkluzi a je užívání výrazu „společné vzdělávání" oprávněné? Pojmy integrace nebo inkluze se v našem slovníku a uvažování objevují díky vývoji výchovně-vzdělávacích systémů směrem k hodnotám rovnosti (equality) a spravedlivosti (equity), které mají vést ke spravedlnosti (justice). Lze dokonce říci, že s pozdní modernitou se tyto hodnoty zdůrazňují tím více, čím více hrozí, že se jim v realitě vzdálíme. ${ }^{2}$

Od začátku 90. let tak probíhalo zařazování dětí s různými znevýhodněními nebo postiženími (později: žáků se „speciálními vzdělávacími potřebami“ SVP) do běžných škol tam, kde došlo k dohodě mezi rodiči a školou. Počet těchto žáků rostl, ale po známé deklaraci ze Salamanky z roku 1994 se objevil pojem inkluzivního vzdělávání pod heslem „pouhá integrace nestačí“.

Analýzy ukazují, že zkrátka nestačí jen formální nárok nebo přístup ke vzdělávání - pro jeho optimální využití je třeba mít také podmínky a nástroje. Proto třeba Lynchová a Baker hovoří o nutnosti zajišt'ovat rovnost podmínek, nejen prŕležitostí a př́ístupu (2005). Ukazuje se, že i když se v mnoha zemích tento formální otevřený př́ístup (access) podařilo uskutečnit, výsledky integrace nebyly vždy uspokojivé. Především se ukázalo, že společné vzdělávání v běžné škole není ani s podporou v zájmu všech žáků se SVP. Záleží na povaze a hloubce znevýhodnění, a proto je nezbytné individuální posouzení každého jednotlivého případu. Většina politik inkluzivního vzdělávání, včetně té české, tuto skutečnost respektuje.

Přibližně kolem roku 2000 podle mne nastal pojmový zmatek vyplývající $\mathrm{z}$ více významů, které pojmy spojené s inkluzivním vzděláváním u různých autorů mají.

Také podle P. Farrella (2002) skutečná inkluze vyžaduje kromě integrace ještě splnění dalších podmínek: akceptaci, participaci a podmínky pro dosažení výsledků (achievement) a probíhá tak ve čtyřech fázích nebo spíše stupních.

2 Na mysli mám zejména stále více se rozrůzňující typy a formy vzdělávání, příliš ranou segregaci žáků do různých typů škol (např. víceletá gymnázia), které vedou ke stále větší rozrůzněnosti kvality a také hodnoty získaného vzdělání - nejen v závislosti na tzv. nadání, ale i podle sociálních, kulturních, ekonomických, etnických a dalších podmínek. 
Integrace, tj. prostá fyzická přítomnost žáků se speciálními vzdělávacími potřebami v běžných školách, představuje absenci exkluze (vyloučení) a je elementární podmínkou společného vzdělávání. Jak ukazují data z matrik MŠMT, tento proces u nás zesílil od druhé poloviny první dekády tohoto století, zejména od roku 2010. Jinak řečeno: i bez proinkluzivní novely výrazně stoupal počet rodičů, kteří požadovali umístění svých dětí se SVP do běžné školy, a počet škol, které jim vyhověly. Dnes je u nás v běžných školách $77 \%$ žáků se SVP. A stejný vývoj platí i pro žáky s lehkým mentálním postižením (LMP). Takzvané praktické školy, které se staly hlavním nositelem odporu proti inkluzivnímu vzdělávání, tedy začaly pocit’ovat jejich úbytek dávno před rokem 2016, kdy vstoupila v účinnost novela schválená na jaře 2015. V té době však nebylo komu připisovat vinu za tento stav. Rodičům? Běžným základním školám? To se paradoxně změnilo s koncem roku 2015, kdy začala příprava implementace novely zákona přinášející zajištění dalších stupňů inkluzivního vzdělávání (podporu materiální, personální i vzdělávací3).

Za další fázi prosazování inkluzivního vzdělávání považuje Farrell akceptaci. Ta je i podle dalších autorů (Barton, 2003; Gordon, 2013) rozhodující pro úspěch inkluze. ${ }^{4}$ Znamená zajistit, že tito žáci budou přijati učiteli, svými spolužáky i jejich rodiči jako plnohodnotní a aktivní členové školní komunity. Dosáhnout naplnění této zdánlivě ,jen“ symbolické či psychologické podmínky však není snadné. Jde o významnou postojovou změnu. Stále přitom hrozí bud' sentimentálně slitovný, „pomáhající“ postoj vedoucí k minimálním nárokům na žáky se SVP, nebo naopak tabuizace odporu $\mathrm{k}$,jinakosti“ vedoucí k separaci (když ne fyzické, tak alespoň vnitřní). Akceptace je silně ovlivněna podmínkami pro společné vzdělávání žáků ve škole a současně je předpokladem jejich udržení, a tedy úspěšné inkluze. Stačí negativní zkušenost s jedním žákem, nepřipravený asistent pedagoga, tvrdohlavý a ke svému dítěti nekritický rodič trvající na nesmyslných požadavcích nebo nárůst „papírování", a akceptace společného vzdělávání je oslabena. Tendence lidí rychle zobecňovat platí i pro učitele.

I povrchní analýza zahraniční literatury ukazuje, že potíže s přijetím vzdělávání žáků se SVP v běžných školách nejsou žádným českým specifikem v důsledku „zpackaného“ pojetí inkluze. Nejfrekventovanějšími pojmy jsou obstacles, resistence a attitude change (typicky viz Curchod-Ruedi et al., 2013).

3 Ponechme $\mathrm{v}$ této chvíli stranou hodnocení, jak byly tyto podpory zajištěny, $\mathrm{v}$ jaké kvalitě a vzájemné korespondenci. 0 tom dále v textu.

4 Podle zkušeností z řady zemí (např. Kanada, Norsko, Španělsko) jde o proces trvající roky (Ebersold, Plaisance, \& Zander, 2016). 
Akceptaci myšlenky inkluze naopak pomáhá, když se vytvoří adekvátní podmínky pro aktivní účast dětí se SVP na většině školních činností, tedy participace. Vyloučeni by měli být jen z minima z nich. Inclusive classroom označuje šířeji třídu, v níž se díky zařazení dětí se SVP daří zlepšovat i situaci ostatních méně výkonných a úspěšných.

Dostáváme se tak k nejnáročnějšímu požadavku či stupni inkluzivního vzdělávání nazývanému achievement. Farrell mluví o stavu, kdy podmínky a př́ležitosti zajištujují, že žáci mají hmatatelné učební výsledky. Jinými slovy, kvalita inkluze se neposuzuje jen na vstupu, podle zajištěných podmínek, vybavenosti, vzdělanosti učitelů atd., ale především na výstupu, podle toho, co tyto děti po čase umějí, jaké výsledky vykazují. To samozřejmě nelze vyhodnotit po jednom roce a měřítkem nemohou být jen jejich vzdělávací výsledky (kognitivní pokrok) ve srovnání s výsledky žáků bez SVP. I zahraniční studie v zemích, kde inkluzivní vzdělávání nastalo mnohem dříve než u nás, tvrdí, že empirické studie zkoumající tyto efekty chybějí (Gordon, 2013). Vedle toho je ovšem nutné připomenout, že stejně tak chybějí empirické longitudinální studie prokazující, že vzdělávání žáků se SVP ve speciálních školách (zejména těch, které vzdělávají žáky s lehkým mentálním postižením) je efektivnější než $v$ př́ípadě jejich začlenění do běžné třídy s podporou. Navíc - je pochybné, zda hlavním cílem inkluze má být především (kognitivní) výkon nebo spíše socializace, kooperace, sdílení.

Teprve celý několikastupňový proces uvedený výše představuje plně inkluzivní vzdělávání. Po zajištění integrace (většinou právním aktem) nastává období vytváření podmínek, posilování akceptace, vylad’ování systému včetně role školských poradenských zařízení a tak dále. To označujeme jako společné vzdělávání směřující k inkluzi.

Na první pohled se tedy situace zdá být jasnou. P. Farrell nicméně upozorňuje, že pozornost těch, kteří prosazují inkluzivní vzdělávání, se výrazně zaměřuje spíše na vnější a formální znaky (finanční náročnost, prostorové vybavení a didaktické, diagnostické, poradenské pomůcky atd.). V celém procesu bychom neměli opominout některé skryté, neuvědomované překážky inkluze. Fungují na implicitní úrovni jako součást našeho antropologického nastavení nebo sociálních a kulturních stereotypů. 


\section{Sociálně-kulturní překážky akceptace inkluze}

Gordon (2013) hovoří v souvislosti s potížemi v zavádění inkluze o tom, že největší bariéry představují naše stereotypy a „mentální návyky“.

Jako první zmiňuje antropologická tabu, ze kterých vyplývají některé „zákazy“ bránící nám uznat, že postižený člověk patří do společenství ostatních, že je jako „my“. Tak jako se v dávnější minulosti postižený trestal ostrakizací a nebylo vhodné s ním komunikovat, tak ještě dnes lidé od postižených osob instinktivně odvracejí pohled. Ona stigmatizace (zejména viditelná) vyvolává bázeň, odtažení, odmítnutí. Tato jinakost sice nebrání setkání a toleranci přítomnosti postiženého, avšak zabraňuje jeho akceptaci. Jsou hodnoty, kterých si naše civilizace cení více než jiných (zdraví, krása, vysoký výkon) - a to pak vyvolává potřebu (se) leckdy urputně překonat při podpoře nějakým způsobem handicapovaných jedinců. Švarcová (2006) konstatuje, že mnoho lidí (včetně řady odborníků, např. lékařů) se domnívá, že postižení lidé by měli být „uklizeni“ do specializovaných zařízení. To podle ní výrazně brzdí jejich začlenění do společnosti cestou vzdělávání. Podobné překážky tematizuje ve své práci o inkluzivním vzdělávání v ČR Pivarč (2015). Zdůrazňuje významnou roli stereotypů a představ o postižených jako „psychosociálních bariér" ve vzdělávání žáků s mentálním postižením.

Zadruhé, chybí etika odlišnosti či jinakosti. Majoritní společnosti, které byly poměrně dlouho uzavřené jinakosti (např. etnicky relativně homogenní společnost s nízkou mírou imigrace), mají potíže s tolerancí nebo uznáním odlišných jedinců. $V$ takové společnosti se respektování odlišných jedincủ často přetavuje do jakéhosi „slitovného“ postoje: ctíme nutnost pomoci slabším a znevýhodněným (charitativní postoj), ale nevnímáme je jako plnohodnotné bytosti, které mají (mohou mít) schopnosti umožňující je zapojit do „našeho světa".

V západních společnostech výkonového charakteru také převažuje étos standardizace. V naší civilizaci jsme během 20. století i pod vlivem pedagogiky a psychologie přijali za svou myšlenku, že vše je nutno podř́́dit co nejrychleji normativním standardům. Efekt testování a výkonových norem v oblasti intelektu, vědomostí i hodnotových orientací a osobnostních vlastností je

\footnotetext{
V př́padě odporu k integraci etnicky odlišných jedinců lze uvažovat i o sociálně-psychologické překážce, kterou můžeme označit jako obranu před sociální devalorizací (před subjektivně pocit’ovaným „pádem níže" ve stratifikaci společnosti). Příslušníci majority, kteří mají nízké postavení, nejsou přátelsky nakloněni integraci lidí $s$ ještě nižším postavením, protože ta z nich dělá stejné „párie“, bere jim předmět převahy nad nimi a znemožňuje jim vidět sama sebe jako ty, kteří nejsou „úplně na dně“.
} 
v tomto ohledu výmluvný. Étosem non-standardizace míní Barton (2003) nezbytnost akceptovat i nestandardní chování jako hodnotu. Takový postoj znamená ptát se po předpokladech, podmínkách, důvodech tohoto chování dříve, než zaujmeme hodnoticí postoj (což neznamená tolerovat za všech okolností vše).

A konečně, významnou překážkou inkluzivního vzdělávání „jiných“ žáků je převažující způsob předávání poznatků/hodnot/postojů ve škole. V ní svádí souboj tzv. seriální (oborový, vědní) kód s kódem integrovaným (např. průřezová témata projektové výuky bližší životu). Učivo i vyučovací metody postavené na kódu oborovém, vnitřně přísně uspořádaném, vedou u dětí $\mathrm{s}$ poruchami učení $\mathrm{k}$ orientaci jen na povrchové př́znaky a struktury $\mathrm{v}$ učivu. Vytvářejí tak u nich pocit nesrozumitelnosti běžného školního prostředí jako něčeho cizího. Aktivní participace na učení by vyžadovala mobilizovat takzvané hluboké struktury. Tomu však nenapomáhá ani př́liš „,na život orientovaná" didaktika. Ta spíše vyvolává chvilkové zaujetí, nikoli hlubší pochopení významu učiva.

Zmíněné překážky se pak promítají i do psychologické argumentace proti (a ovšem i pro) rozšíření inkluzivního vzdělávání.

\section{Psychologické překážky - „gausismus“ vs. optimismus změny}

V zahraniční literatuře je za nejvýznamnější bariéru považováno tzv. esencialistické uvažování (Ebersold, Plaisance, \& Zander, 2016).

Gillborn a Youdellová (2001) již na začátku milénia poukázali na to, že rostoucí individualismus v kontextu tlaku na výkon a soutěž přinesl návrat esencialistické logiky. Ta vychází z dříve vyvrácených přesvědčení, že intelektové předpoklady jsou víceméně dané a neměnné. Každý se $s$ nimi rodí. $V$ této logice se podobně uvažuje i o dalších schopnostech člověka. Praktickým důsledkem je pak mínění, že každý si zaslouží své zařazení ve vzdělávacím systému, a proto selektivní systém odpovídá „přirozenému“ rozložení individuálních předpokladů lidí. ${ }^{6}$ Odkaz k „přirozenosti“ a idea korespondence

\footnotetext{
Není zde prostor rozebírat tvrzení některých sociologů (nejsilněji Bourdieu), že je tomu přesně naopak - mocenské poměry a distribuce sociálních institucí vytváří či posilují ideu přirozené distribuce schopností lidí. Lidé s převahou názorného a praktického myšlení končí jako „manuálové“, lidé abstraktního myšlení v intelektuálních profesích. A to je připravováno už různými typy škol ve vícekolejných systémech vzdělávání.
} 
sociálních institucí (školy) této „přirozené“ distribuci tvoří sílu přesvědčení, že inkluzivní vzdělávání žáků se SVP je nesmyslná utopie.

Heslo „přizpůsobit školu individuálním zvláštnostem dětí“ je pak vykládáno jako platné především pro žáky bez nějakých výrazných potíží nebo postižení. Pro žáky se SVP představuje ono přizpůsobení nikoli adaptaci přístupu, metody, didaktické experimentace, ale zařazení do jiné školy, kde budou vzděláváni se „sobě rovnými“.

Variací na uvedené přesvědčení, ovšem ve vědeckém hávu, je argumentace Gaussovou křivkou. Ta samozřejmě u parametrických dat platí, nicméně právě u měření intelektových schopností jde o data tak silně závislá na nástroji měření, na jeho kontextu i na dosavadních podmínkách života žáka, že argumentaci Gaussovou křivkou v ideologických sporech lze kriticky označit jako „gausismus“. Ten zanedbává efekt sociokulturních i vzdělávacích vlivů. Gaussova křivka tedy stále platí, ale jestliže jedinci, kteří se před 100 lety svým výkonem v inteligenčním testu nacházeli na úrovni druhé směrodatné odchylky pod průměrem, nedokázali určit dny v týdnu nebo přečíst slovo, dnes jedinci na této úrovni díky demokratičtější kultuře př́stupu ke vzdělávání a propracovanějším nástrojům vzdělávání tyto úkony ovládnou.

Argumentace „Gaussem“ tedy nedoceňuje „genetický"7 vliv sociálních, kulturních i pedagogických podmínek na rozvoj psychologických předpokladů školního úspěchu. Ignoruje se tak celá řada kulturně-psychologických výzkumů, které v inspiraci L. S. Vygotským dokládají vliv kultury na kognitivní (psychický) vývoj.

Zmínit je možné klasický Lurijou provedený (a Vygotským vedený) terénní výzkum vlivu kolektivizace na poznávací procesy lidí (Lurija, 1976) na počátku

Genetickým vlivem vůbec nemyslíme předávání genetické informace biologickou cestou. Tento pojem zde označuje skutečnost, že specificky lidské psychické funkce se "rodí“ (generují) a rozvíjejí v kulturně-sociálních situacích, jsou zásadně ovlivněny na jedné straně podobou kulturních děl (jazyk, písmo, věda, víra atd.), která zanechaly předchozí generace a se kterými má (nemá) dítě možnost se setkat. A na druhé straně jsou ovlivněny kvalitou podpory druhých lidí - a to již od narození. Takto kulturně jsou formovány nejen vyšší kognitivní procesy, ale třeba vnímání, pozornost, vůle atd. 
30. let minulého století. ${ }^{8}$ Podobně překvapující efekt přineslo Oléronovo ověřování Piagetových operačních zkoušek na populaci v zemích Maghrebu v 60. letech. A klasické jsou dnes již výzkumy M. Colea, S. Scribnerové nebo J. Laveové provedené v 70. letech v Libérii a dokazující závislost intelektových výkonů a motivace $\mathrm{k}$ nim na každodenních činnostech, kulturních návycích a podnětech. Od poslední třetiny 20 . století se ví, že bez kvalitativní diagnostiky rozvojového potenciálu jedince vzhledem k sociokulturním podmínkám jeho života je posouzení jeho předpokladů nedostatečné.

Významným argumentem proti gausismu je teorie a hlavně praxe Feuersteinova programu instrumentálního obohacování (FIE). V něm zacílené „trénování“ jednotlivých kognitivních funkcí ukázalo, jak významné je pro psychický vývoj kvalitní vedení vychovatelem, který žákovi zvědomuje jednotlivé mentální úkony a činí z nich předmět kultivace. To pak žákovi umožňuje užívat je jako nástroje v intelektuálních činnostech (Feuerstein et al., 2014). Pedagogický koncept kognitivní modifikovatelnosti (změnitelnosti) přitom vznikal v empirickém výzkumu a vzdělávacích projektech určených dětem postiženým a sociálně a kulturně znevýhodněným (váleční sirotci, handicapovaní, málo gramotní židovští imigranti z Etiopie).

Podobné argumenty lze opřít i o výzkumy a programy rakouské psycholožky Brigitte Sindelarové zaměřené na odstraňování „deficitů dílčích funkcí", jako jsou zrakové vnímání, sluchové vnímání, prostorová orientace, intermodální spojení a vnímání časového sledu. Také v tomto případě jde o propojení diagnostiky s intervencí či vzdělávacím působením (Sindelar, 2013).

Avšak i autoři, kteří nepracovali v uvedeném paradigmatu, předložili nálezy, které volají po prozkoumání vlivu kultury a vzdělávání na psychické funkce. Lze např́klad uvést poměrně diskutabilní a diskutovaný (tzv.) Flynnův efekt. Ten ukazuje, že se probandi v dlouhém časovém horizontu u stejných položek inteligenčního testu zlepšují, a to tak, že za padesát let může jít o zlepšení až o jednu směrodatnou odchylku (15 bodů IQ testu). Interpretace prŕćčin se pak pohybuje od zlepšení výživy obyvatelstva přes větší obeznámenost

\footnotetext{
Populace původně negramotných obyvatel uzbecké vesnice byla po sovětské revoluci rozdělena do několika skupin od negramotných žen žijících i ve vesnici zcela izolovaně ve svých domácnostech přes nevzdělané rolníky spolupracující v družstvu až po z vesnice vzešlé středoškolačky. Všechny skupiny byly podrobeny testování psychických funkcí od vnímání tvarů a barev přes řešení sylogismů až po reflektující sebehodnocení. Výsledky konstatovaly rozhodující vliv sociálních (četnost a kvalita interakce a komunikace s druhými) a kulturních (školní vzdělání) faktorů na úroveň těchto funkcí.
} 
lidí s druhy předkládaných úkolů až po efekt systematické povinné školní docházky a zvýšení úrovně všeobecné vzdělanosti (Flynn, 1984, 1998). Společná všem interpretacím je ovšem negace neměnnosti rozumových předpokladů.

Uvedené výzkumy prokázaly, že kombinace tradiční diagnostiky a „nácviku“ (instrukce odhalující logiku úloh) pomáhá velké části původně „postižených" - chyba však není v nástroji samotném, ale v celkovém přístupu. Není proto divu, že se v teorii i v praxi stále více prosazuje takzvaná dynamická diagnostika. ${ }^{9}$ Ta ovšem vyžaduje změnu práce psychologů a speciálních pedagogů v poradenských zařízeních.

Zavádění inkluzivního vzdělávání zaměřeného na žáky s nějakým postižením tak staví do popředí nezbytnost kvalitativního posouzení nejen aktuální úrovně schopností žáka, ale zejména jeho schopnosti využít instrukce. Cílem posouzení je zjistit potenciál pokroku, který žák učiní za pomoci učitele (jde o praktickou aplikaci pojmu zóna nejbližšího vývoje žáka). Předpokládá nejen zjištění aktuální úrovně jeho výkonů, ale také jeho tzv. adaptability. K tomu je třeba jednak dostatek validních, standardizovaných nástrojů diagnostiky rozumových i adaptivních schopností, jednak také zajištění kvalitní „dopomoci“, tj. zajištění přípravy žáka v chybějících prerekvizitách jazykových, komunikačních, operačních připraveným pedagogem, zapojením speciálních pedagogů do vzdělávání v běžných školách, vytvořením materiálních a organizačních podmínek pro práci s ním (nimi), úpravami kurikula a tak dále.

A právě nedostatky $\mathrm{v}$ zajištění těchto podmínek byly důvodem kritiky části naší odborné pedagogické veřejnosti na adresu inkluze.

Proč by ale tyto postupy nemohly být dokonce organizačně lépe zajištěné ve speciálních školách ve skupině žáků s podobnými potížemi? Není pochyb, že ve speciálních školách je také možné nastavit pedagogické postupy směřující k využívání zóny nejbližšího vývoje (např. Brunerem popularizované metody „lešení"). Ve společenství zdravých žáků se však může žák se SVP spíše seznámit s tím, jak se jiní učí jinak. Zažije a upevní pocit sounáležitosti s ostatními (jinými), zvyšuje se motivace a očekávání vůči sobě. Velmi často může zažít, že ostatní ocení jeho byt' malý pokrok. To vše samožrejmě

\footnotetext{
Dynamická diagnostika kombinující zjištění úrovně „zde a nyní“ s nácvikem řešení testových úloh a jim odpovídajících úkolů a činností; v mimotestových situacích se zaměřuje na zjištování potenciálu dítěte, na proces (a nejen na aktuální výsledek), a je doporučovaná jako hlavní diagnostický přístup u dětí se SVP, příslušníků minorit a dětí tzv. hraničních (Tzuriel, 2001).
} 
nastat nemusí - záleží na ochotě, zaujetí, zkušenostech a vyškolení pedagogů i na étosu konkrétní školy. Společné vzdělávání však vytváří podmínky pro kulturu respektu, posiluje pocit sounáležitosti a je př́ležitostí dozvědět se něco o rozdílech mezi lidmi a tyto rozdíly akceptovat (Bonvin, 2013).

Co nám tedy říká realita prvního roku implementace proinkluzivní novely školského zákona u nás?

\section{$4 \quad$ Inkluze rok první: nic se nestalo nebo nepřipravená komplikace?}

V souladu se zahraničními zkušenostmi lze tvrdit, že na vyhodnocení úspěšnosti společného vzdělávání je ještě brzy. Nicméně, statistická data o prvním roce implementace máme $\mathrm{k}$ dispozici, stejně jako řadu individuálních př́běhů. Kvalitativní výzkum ve čtyřech základních školách, které vzdělávaly žáky se SVP dlouho před rokem 2016, provedla D. Moree (2018). Dotazníkové šetření s reprezentativním vzorkem 126 ředitelů a 507 učitelů ZŠ uskutečnila agentura Nielsen Admosphere (zadaly ho OSF, ČOSIV a ČMOS PŠ; Nadace Open Society Fund, 2018). A konečně samo MŠMT již v červnu 2017 zadalo komplexní analýzu prvního roku společného vzdělávání, z níž bohužel zveřejnilo pouze jakési manažerské shrnutí (MŠMT, 2018). Pro srovnatelnost se budu věnovat zejména datům ze ŽS.

\subsection{Statistická data: nic se nestalo}

Analýza MŠMT za školní rok 2016/2017 zahrnula nejen srovnání základních údajů z matrik mezi „rokem před inkluzí a prvním rokem implementace novely, ale také srovnání s předešlými lety (od r. 2010). To umožnilo několik konstatování:

1) Počet dětí a žáků ve speciálních školách se od roku 2010 dlouhodobě snižuje. Nelze tak jednoznačně tvrdit, že ve speciálních školách ubývá dětí v důsledku implementace inkluze. Navíc, řada speciálních škol, pokud se sloučí s běžnou školou, je ve výsledku pak již považována za běžnou školu (ale v praxi je to de facto nadále „samostatné" pracoviště, kde jsou jen děti se SVP, často právě s LMP, ale pod společným ředitelstvím s běžnou školou). Za poslední rok došlo v ZŠ k nárůstu žáků se zdravotním postižením o jedno procento na $10,3 \%$, avšak roste také počet dětí se SVP zařazených do běžných škol $(77 \%$ z nich, a to zejména integrovaných individuálně, nikoli ve speciální třídě běžné ZŠ). 
2) Paradoxem je, že se zavedením podpůrných opatření se úbytek žáků ve speciálních školách zpomalil. Od září 2015 do záŕí 2016 (rok před proinkluzivní novelou) jich ze speciálních škol do škol běžných přešlo 1549 , opačným směrem $\mathrm{z}$ běžných tříd/škol do tříd a škol speciálních jich přešlo 2 212. Co se změnilo po aplikaci novely zákona? Ze speciálních škol do škol běžných od záŕí 2016 do září 2017 přešlo 1138 žákủ (o 411 méně) a opačným směrem bylo speciální školství posíleno 2455 žáky (tedy o 243 více)!

3) Významně narůstají především počty žáků s vývojovými poruchami učení nebo chování (VPUCH). Žáků s LMP se proinkluzivní opatření dotkla statisticky nevýznamně. Nárůst počtu žáků se VPUCH může být částečně důsledkem nové kategorizace podpory podle míry obtíží žáka, protože nyní mají i žáci s nižším stupněm tohoto znevýhodnění nárok na podpůrná opatření (PO). Data potvrzují, že v této kategorii žáků jsou také žáci v pásmu hraničního intelektu, pro které nebyl původně zaveden vlastní identifikátor znevýhodnění. Je tedy velmi pravděpodobné, že právě tato skupina žáků přispěla k rozšíření kategorie znevýhodnění VPUCH. Drtivá většina těchto žáků však již předtím v Z ̌Š byla.

4) Nejčastěji vykázaným podpůrným opatřením (PO) byla pedagogická intervence ve škole (1 hodina), tedy činnost, která je součástí základního vybavení učitele (doučování, vysvětlování, opakování, pomoc s úkoly). Byla vykázána téměř 10 tisíckrát, z toho více než v 80 \% př́ípadů s požadavkem na finanční prostředky. Nejnákladnějšími však bylo PO asistent pedagoga (AP). Bylo jich vykázáno v přepočtu na úvazky více než 4,1 tisíce, z toho téměř 3,6 tisíce (87\%) s požadavky na finance (finanční nároky na toto PO tak odpovídají více než 1,345 mld. Kč).

5) Počet $A P$ ve všech školách $v$ posledních letech nepřetržitě roste. Jen od školního roku 2010/2011 k 30. 9. 2016 se zvýšil o 5 212,2 úvazku, tedy o více než $144 \%$. Pokud jde o efekt proinkluzivní novely, k 30. 9. 2016 bylo vykázáno 13299 AP, k 30. 9. 2017 pak 17725 AP, což představuje nárůst o 4426 fyzických osob.

6) Školská poradenská zařízení (ŠPZ) začala více spolupracovat se školou a rodiči; odvrácenou stranou je však obrovský nárůst administrativy a jejich přetížení. Mnohá však stále fungují jen formálně, nekomunikují o obsahu doporučených $\mathrm{PO}$, přidělují $\mathrm{PO}$ neúčelně nebo nezdůvodněně (zejména AP). 
Z pohledu velkých statistických dat tedy

- nedošlo k žádnému skokovému přesunu žáků se SVP ze speciálních škol do škol běžných. Do běžných škol přešli ti žáci, jejichž znevýhodnění v nich umožňuje vzdělávání s podporou. $V$ řadě př́ípadů došlo $\mathrm{k}$ úspěšné integraci žáků se SVP do běžných škol - týká se to jak žáků s LMP, tak tělesně postižených či žáků se smyslovým postižením;

- nedošlo k žádnému oslabení speciálního školství. Systém PO paradoxně podpořil i žáky speciálních škol;

- žákům se SVP v běžných školách se dostalo strukturované podpory, což oceňují rodiče i školy. Oproti minulosti školy věděly, na co a za jakých podmínek mají žáci nárok;

- začaly se více odhalovat a řešit problémy se žáky s poruchami chování a s autismem, které představují pro školy největší zátěž z pohledu nároků na práci pedagoga.

Na druhou stranu implementaci společného vzdělávání komplikovala

- náročná administrativa spojená s nárokovými PO;

- nedostatečná připravenost pedagogů běžných škol v oblasti speciálněpedagogických dovedností;

- další vzdělávání podporující implementaci společného vzdělávání se zaměřilo jen na dílčí témata.

Výběrová a kvalitativní šetření však kromě potvrzení pozitiv zmíněných výše přinesla také řadu varování.

\subsection{Kvalitativní analýzy: akceptace napůl, problémů stále dost}

Jak šetření Nadace Open Society Fund (2018), tak výzkum D. Moree ve školách provozujících dlouhodobě inkluzi (2018) potvrdily názor ředitelů a v menší míře i učitelů, že inkluzivní vzdělávání je krok dobrým směrem s mnohými „ale“. Pozitivní je, že se toto téma dostalo do povědomí veřejnosti (třeba i kriticky) a více se o něm ví a mluví. Přibyly finance, je více pedagogického personálu, oceňují se placené pedagogické intervence a cílený nákup pomůcek. 
Mezi varovné momenty nicméně patří:

- „zavalení bez podpory“ (Moree, 2018, s. 7) - a to jak administrativou související s nepružným systémem vykazování, změn a hodnocení efektivity PO, tak prostě nárůstem práce související s podporou žáků se SVP (intervence u žáků, nápravy, práce s AP atd.). Tedy - peněz přibylo, ale práce ještě mnohem více. Zajímavé ovšem je, že podle šetření OSF považuje administrativní zátěž spojenou s inkluzí za př́liš velkou jen polovina dotazovaných ředitelů a druhá polovina nikoli;

- celkově velmi složitý systém kombinující individuální adresnou pomoc (vyšetření, doporučení, hodnocení) a zaměření na celé skupiny zdravotního postižení či sociokulturního znevýhodnění, a to ještě nejen ve škole, ale v různých typech školských zařízení (Demeuse et al., 2012, přitom plédují pro jednoduché vymezení cílových kategorií);

- decentralizovaný systém školství, který po zániku odvětvového řízení vede $\mathrm{k}$ velmi odlišné situaci $\mathrm{v}$ různých krajích (zaznamenáváme např. obrovské až záhadné rozdíly v nárůstu, nebo naopak v úplné absenci některých postižení), což lze interpretovat trojím způsobem: (i) politické vedení kraje není inkluzi nakloněno do té míry, že zákon, vyhlášky a metodiky ignoruje (viz nelegální podpora speciálních škol prostřednictvím PO), (ii) pracovníci ŠPZ nebo školy přistupují k inkluzi zcela formálně a vyhoví každému přání rodiče nebo školy (viz výše zmíněný rozptyl počtu PO na žáka); (iii) ani profesionálové v terénu nemají dost informací, respektive si poměrně složitý systém neosvojili, takže pod tlakem dělají více chyb než obvykle;

- pocity bezmoci učitelů běžných škol, kteří na práci $s$ „jinými“ nejsou připraveni;

- základní informovanost o společném vzdělávání, která se sice podle deklarací respondentů zdá být dobrá, ale týká se to hlavně legislativních témat;

- naprosto nedostatečné vzdělávání pedagogů a také AP pro individualizovanou práci s dítětem se SVP již na učitelských fakultách, ale také v dalším vzdělávání, ve kterém velké škody na akceptaci inkluze působí nejasné a často protichůdné informace MŠMT, NÚV, krajů, lektorů NIDV ad.;

- obava, zda bude financování PO pokračovat v dostatečné míře, vyvolaná zneklidňujících výroků politiků a některých médií. 
Pohled „zevnitř““ (emic) ukazuje, že společné vzdělávání tak, jak bylo spuštěno, obecně nevyvolává jednoznačný odpor. Přesto je evidentní, že ještě dlouho bude debata o inkluzi poměrně kontroverzní. A nelze to svádět jen na její apriorní a trvalé odmítání zájmovou skupinou speciálních pedagogů z bývalých praktických ZŠ a politiků a médií podporujících je. ${ }^{10}$ Postoj učitelů je přitom znatelně vlažnější než postoj ředitelů škol. Zatímco u ředitelů v tom zřejmě hraje velkou roli př́ísun financí přímo do škol, který jim navíc zvyšuje díky vytváření „rezerv“ ve využívání PO autonomii v odměňování učitelů, u učitelů hraje roli každodenní tlak nejen na pedagogické řešení konkrétních problémů. I dosud existující podpora společného vzdělávání může klesnout na bod mrazu, pokud se nezjednoduší administrativa, nezajistí menší počet žáků ve třídách a nepřipraví kvalitní, jednoznačné informování a hlavně vzdělávání v tématu pedagogických praktik určených pro heterogenní třídy. To, co je dnes záchrannou kotvou, se rychle může změnit $\mathrm{v}$ důvod silného odmítnutí (snížením financování, oslabením podpůrných opatření).

\section{Závěr}

Je evidentní, že pozornost se musí výrazně více věnovat otázce „jak“, tedy praktickým pedagogickým a organizačním postupům $v$ jednotlivých př́ípadech. At' už jde o děti a žáky v běžných školách, nebo o ty, v jejichž zájmu je vzdělávat se ve školách speciálních, všude je jako pod zvětšovacím sklem před pedagogy, psychology i speciálními pedagogy výzva: změnit pedagogická přesvědčení a postoje a nebát se didakticky experimentovat a zkoušet. To je v systému a v atmosféře „inženýrsky“ dokonale fungujícího mechanismu podle standardních postupů šitých na míru modálnímu bezproblémovému žákovi velmi obtížné.

Statistiky za posledních deset let ukazují, že vzdělávání dětí se SVP společně s ostatními žáky zrušit či zastavit nejde. Ted' jde o to, abychom se přiblížili skutečné inkluzi. Tak komplexní změnu nikdy nelze dokonale předem připravit ve stylu „ready made“. Klíčové proto bude, jak zvládneme flexibilně reagovat na nefunkční prvky a zajistit přiměřené podmínky a skutečnou participaci žáků se SVP zařazených do běžných škol. Jen tak může po letech dojít k akceptaci myšlenky inkluzivního vzdělávání.

10 Nejsme v tom sami - přehledová studie McLeskeyho (2004) analyzující nejcitovanější články ve speciálněpedagogických časopisech ukázala, že téma inkluzivního vzdělávání v běžných školách je nejčetnější a také nejkontroverznější (z 50 článků se jich tímto tématem zabývalo 20 a tři z nich tematizovaly úplnou inkluzi se zrušením speciálního školství). 


\section{Literatura}

Barton, L. (2003). Inclusive education and teacher education. A basis for hope or a discourse of delusion. London: Institute of Education, University of London. Dostupné z http:// disability-studies.leeds.ac.uk/files/library/Barton-inclusive-education.pdf

Bonvin, P., Ramel, S., Curchord-Ruedi, D., Albanese, O., \& Doudin, P.-A. (2013). Inclusion scolaire: de l'injonction sociopolitique à la mise en oeuvre de pratiques pédagogiques efficaces [Inclusive education: From a sociopolitical agenda to the implementation of effective educational practices?]. ALTER, European Journal of Disability Research, 7(2), 127-134.

Curchord-Ruedi, D., Ramel, S., Bonvin, P., Albanese, O., \& Doudin, P.-A. (2013). De l'intégration à l'inclusion scolaire: implication des enseignants et importance du soutien social [Integration and inclusive education: Teachers' involvement and importance of social support]. ALTER, European Journal of Disability Research, 7(2), 135-147.

Demailly, L. (1987). La qualification ou la compétence professionnelle des enseignants. Sociologie du travail, 1, 59-70.

Demeuse, M., Frandji, D., Greger, D., \& Rochex, J.-Y. (Eds.). (2012). Educational policies and inequalities in Europe. London: Palgrave Macmillan.

Ebersold, S., Plaisance, E., \& Zander, C. (2016). École inclusive pour les élèves en situation de handicap: accessibilité, réussite scolaire et parcours individuels. Paris: UNESCO.

Farrell, P. T., \& Ainscow, M. (Eds.). (2002). Making special education inclusive: From research to practice. London: Fulton.

Feuerstein, R., Feuerstein, R. S., Falik, L., \& Rand, Y. (2014). Vytváření a zvyšování kognitivní modifikovatelnosti. Praha: Karolinum.

Flynn, J. R. (1984). The mean IQ of Americans: Massive gains 1932 to 1978. Psychological Bulletin, 95, 29-51.

Flynn, J. R. (1998). IQ gains over time: Toward finding the causes. In U. Neisser (Ed.), The rising curve: Long-term gains in IQ and related measures (s. 25-66). Washington: American Psychological Association.

Gillborn D., \& Youdell D. (2001). The new IQism: Intelligence, 'ability' and the rationing of education. In J. Demaine (Ed.), Sociology of education today (s. 65-99). London: Palgrave Macmillan.

Gordon, J.-S. (2013). Is inclusive education a human right? Journal of Law, Medicine and Ethics, 41(4), 754-767.

Janík, T. (2013). Od reformy kurikula k produktivní kultuře vyučování a učení. Pedagogická orientace, 23(5), 634-663.

Lurija, A. R. (1976). O historickém vývoji poznávacích procesủ. Praha: Academia.

Lynch, K., \& Baker, J. (2005). Equality in education: An equality of condition perspective. Theory and Research in Education, 3(2), 131-164.

McLeskey, J. (2004). Classic articles in special education: Articles that shaped the field, 1960 to 1996. Remedial and Special Education, 25(2), 79-87.

Moree, D. (2018). Systém v ne-systému aneb inkluze rok poté. Praha: Nadace OSF.

MŠMT. (2018). První rok společného vzdělávání - hlavní závěry 2. analýzy. Praha: MŠMT. Dostupné z http://www.msmt.cz/file/46497/ 
Nadace Open Society Fund. (2018). Rok poté - dopady reformy společného vzdělávání. Praha: Nadace OSF. Dostupné z https://skolskeodbory.cz/sites/skolskeodbory.cz/files/ downloads/1521095263/rok_pote_-_dopady_reformy_spolecneho_vzdelavani_-_2018.pdf.

Pivarč, J. (2015). Pupils' misconceptions as a psychosocial barrier in the context of inclusive education [Błędne wyobrażeniauczniów jako bariera psychospołeczna w kontekście edukacji włączającej]. Studia Edukacyjne, 37, 363-376.

Schleicher, A. (2018). Valuing our teachers and raising their status. How communities can help. Dostupné z http://www.oecd.org/education/valuing-our-teachers-and-raising-theirstatus-9789264292697-en.htm

Sindelar, B. (2013). Předcházíme poruchám učení: soubor cvičení pro děti v předškolním roce a v první třídè. Praha: Portál.

Straková, J. (2013). Jak dál s kurikulární reformou. Pedagogická orientace, 23(5), 734-743.

Štech, S. (2013). Když je kurikulární reforma evidence-less. Pedagogická orientace, 23(5), 615-633.

Tonucci, F. (1992). Vyučovat, nebo naučit? Praha: Pedagogická fakulta UK.

Tzuriel, D. (2001). Dynamic assessment of young children. New York: Kluwer Academic/Plenum Publishers. 